\title{
A Study of Exclusive Breast Feeding in Premature and Low Birth Weight Infants Less than Six Months of Age in Hillah City Babylon Province
}

\author{
Sijal Fadhil Farhood Makki ${ }^{\mathrm{a}}$ \\ Ihab Raad Abbas Abid Ali ${ }^{\text {b }}$ \\ ${ }^{a}$ Department of Community Medicine, College of Medicine, University of Babylon \\ ${ }^{b}$ Hillah General Teaching Hospital Babylon Health Directorate \\ 78sijal@gmail.com sijalaljoborae@yahoo.com
}

Submission date:- 8/4/2018 Acceptance date:- 22/5/2018 Publication date:- 19/11/2018

Keywords: Breast feeding,Prematurity,Low birth weight.

\begin{abstract}
A hospital based descriptive cross-sectional study was conducted to describe the prevalence of exclusive breast feeding in premature and low birth weight infants. The study included 200 infants in Hillah city Babylon Province, whose ages were less than six months. Catchments of these infants was in the neonatal /special care baby units and the general wards in both Hillah General Teaching Hospital and Babil Maternity Teaching Hospital in Babylon Governorate during the period from the first of January 201^ till the end of March 2018.

The infants' mothers came from mixed urban and rural backgrounds. Socio -demographic variables related to infants and their mothers' obstetric data were recorded. Neonatal data was extracted from the medical records of the labor and neonatal care wards. The study included mothers of all ages, one in six of whom (16\%) were teenagers marrying at a young age. $52 \%$ of the older respondents reported being married during their teenage years. Since all the babies included in the study were either preterm or low birth weight, the mean birth weight was $(1894.00 \pm 464.15) \mathrm{gm}$ (LBW) and the mean gestational age was $(34.42 \pm 2.84)$ weeks (preterm). The study outlined three main groups of reasons in order of frequency for quitting exclusive breast feeding, the first group involved the following reasons (milk was of poor quality, breast milk causes jaundice or diarrhea or a previous child didn't thrive on breast feeding) $(53.7 \%)$, the second group covered reasons related to (advice from doctor/medical staff, or non-medically qualified person) (22\%)and the third group was because of (LBW and prematurity per se)(14.6\%).
\end{abstract}

\section{1- Introduction}

In Iraq mothers of preterm and or low birth weight (LBW) infants are confused about the benefits of breast feeding, they think that their babies have special needs that are not met by their natural milk. Their primary intention is to increase the weight of preterm and/or (LBW) infants at any cost even if it is at the expense of the neurological and hematological needs.

Mothers (usually teenagers with a primary level of education) express concern about having inadequate amounts of breast milk or poor quality of their breast milk.

Concern that a mother could potentially harm her infant through breast feeding are rooted in a belief of an inherited inability to produce milk, having 'bad milk'[1].

Scientific evidence shows that preemies don't need breast milk less than full term infants, they need it more [2].Breast milk for preterm and low birth weight infants provides protection against infection, protection against 
necrotizing enterocolitis, appropriate lipid profile(PUFA's), better cognitive development and better visual development. Low birth weight (LBW) babies are defined as babies with birth weight less than 2500g [3]. These could be either term small for gestational age (term SGA) or preterm babies. LBW is a common problem in our country with an incidence of $30-40 \%$ (term SGA $20-30 \%$ and preterm 10-20\%). Although it is generally agreed that human milk is the ideal source of nutrition for full term neonates, there is controversy regarding human milk as a nutrition source for preterm and low birth weight infants. Some opinions vary from its being the best even if it needs the addition of several supplements, to that there is no place for breast milk in preterm nutrition [4]. However, data is emerging to support the use of human milk for LBW infants. None of the substitute feeds can match the qualitative properties of human milk. Nature has modified the breast milk of the mother of a preterm baby so as to make it the ideal and the best option for the LBW neonates [5].

\section{2- Material and methods:}

This study was conducted in both Hillah General Teaching Hospital and Babil Maternity Teaching Hospital in Babylon Governorate during the period from the first of January 2018 till the end of March 2018.

\section{3- Study population:}

The study included 200 infants who were either premature and/or low birth weight and whose age were under six months, catchments of these infants were either in the neonatal /special care baby unit or the general wards in the above mentioned hospitals. The data was gathered, after consent was granted; using a specially designed questionnaire in addition to information collected from the special care baby unit admission files. The sampling method is convenient (non-probability method).

\section{4- Study design:}

The study is a hospital based descriptive cross-sectional study that was conducted to describe the prevalence of exclusive breast feeding in premature and low birth weight infants whose current age were less than six months.

Reasons for quitting exclusive breast feeding were also documented, The main study variables included ( current maternal age, maternal age at marriage, residence ,educational status, baby gender,birth weight, gestational age at birth, spacing between births, type of delivery whether normal vaginal or Caesarean section).

Major variables include the type of feeding in the first six months of infant's life whether (exclusive breast feeding )or (mixed and artificial feeding).

\section{5- Data Analysis:}

Statistical analysis was carried out using SPSS version 18. Categorical variables were presented as frequencies and percentages. Continuous variables were presented as (Means \pm SD). Pearson's chi square (X2) test and fisher exact test were used to find the association between the categorical variables, t-test was used to show the mean difference,correlation, A p-value of $\leq 0.05$ was considered as the level of significance.

\section{6- Results:}

Table 1:Mean and Standard Deviation of Current Maternal Age(year), Maternal Age at Marriage(year), Birth Weight (gram) and Gestational Age(week) of the Study Population.

\begin{tabular}{|c|c|c|}
\hline Variables & Mean \pm SD & Range \\
\hline Current maternal age(year) & $26.97 \pm 6.76$ & $(15-39)$ \\
\hline Maternal age at marriage(year) & $19.45 \pm 5.10$ & $(12-36)$ \\
\hline Birth weight(gm) & $1894.00 \pm 464.15$ & $(1893-2750)$ \\
\hline Gestational age(weeks) & $34.42 \pm 2.84$ & $(27-40)$ \\
\hline
\end{tabular}


Table 1 shows that the mean age of the mothers who participated in the study is $(26.97 \pm 6.76)$ years and the mean age at marriage is $(19.45 \pm 5.10)$ years.

Since all the babies included in the study were either preterm or low birth weight, the mean birth weight is $(1894.00 \pm 464.15) \mathrm{gm}(\mathrm{LBW})$ and the mean gestational age is $(34.42 \pm 2.84)$ weeks (preterm).

Table 2: Distribution of Mothers by Socio-demographic Characteristics ( $\mathbf{N = 2 0 0 )}$.

\begin{tabular}{|c|c|c|}
\hline Variables & Number & Percentage(\%) \\
\hline \multicolumn{3}{|l|}{ Current maternal age(year) } \\
\hline $10-19$ & 32 & $16 \%$ \\
\hline $20-35$ & 142 & $71 \%$ \\
\hline$>35$ & 26 & $13 \%$ \\
\hline Total & 200 & $100 \%$ \\
\hline \multicolumn{3}{|l|}{ Maternal age at marriage(year) } \\
\hline$<20$ & 104 & $52 \%$ \\
\hline $20-35$ & 92 & $46 \%$ \\
\hline$>35$ & 4 & $2 \%$ \\
\hline Total & 200 & $100 \%$ \\
\hline \multicolumn{3}{|l|}{ Maternal education } \\
\hline Illiterate & 44 & $22 \%$ \\
\hline Primary education & 120 & $60 \%$ \\
\hline Secondary education & 24 & $12 \%$ \\
\hline Higher education & 12 & $6 \%$ \\
\hline Total & 200 & $100 \%$ \\
\hline \multicolumn{3}{|l|}{ Residence } \\
\hline Rural & 84 & $42 \%$ \\
\hline Urban & 116 & $58 \%$ \\
\hline Total & 200 & $100 \%$ \\
\hline \multicolumn{3}{|l|}{ Employment } \\
\hline Employed & 16 & $8 \%$ \\
\hline House wife & 184 & $92 \%$ \\
\hline Total & 200 & $100 \%$ \\
\hline \multicolumn{3}{|l|}{$\begin{array}{l}\text { Returning to work within: } \\
\qquad(\mathrm{n}=16)\end{array}$} \\
\hline Less than 6 months & 12 & $75 \%$ \\
\hline More than or equal to 6 months & 4 & $25 \%$ \\
\hline Total & 16 & $100 \%$ \\
\hline
\end{tabular}


Table 2 shows that mothers who participated in the study are married at a relatively young age,52\% are aged less than 20 years, $82 \%$ of these women are either illiterate or have primary level of education, $92 \%$ are housewives.

Table 3: Distribution of Neonates by Socio-demographic Characteristics $(\mathrm{N}=\mathbf{2 0 0})$.

\begin{tabular}{|c|c|c|}
\hline Variables & Number & Percentage $(\%)$ \\
\hline \multicolumn{3}{|l|}{ Birth weight(gm) } \\
\hline$<1000$ & 8 & $4 \%$ \\
\hline $1000-1499$ & 28 & $14 \%$ \\
\hline $1500-2499$ & 140 & $70 \%$ \\
\hline$\geq 2500$ & 24 & $12 \%$ \\
\hline Total & 200 & $100 \%$ \\
\hline \multicolumn{3}{|l|}{ Gender } \\
\hline Male & 108 & $54 \%$ \\
\hline Female & 92 & $46 \%$ \\
\hline Total & 200 & $100 \%$ \\
\hline \multicolumn{3}{|l|}{ Gestational age(weeks) } \\
\hline$<37$ (preterm) & 140 & $70 \%$ \\
\hline$\geq 37$ & 60 & $30 \%$ \\
\hline Total & 200 & $100 \%$ \\
\hline \multicolumn{3}{|l|}{ Type of delivery } \\
\hline Normal vaginal delivery & 84 & $42 \%$ \\
\hline Emergency C-section & 68 & $34 \%$ \\
\hline Elective C-section & 48 & $24 \%$ \\
\hline Total & 200 & $100 \%$ \\
\hline \multicolumn{3}{|l|}{ Number of babies } \\
\hline Singleton & 188 & $94 \%$ \\
\hline Multiple & 12 & $6 \%$ \\
\hline Total & 200 & $100 \%$ \\
\hline
\end{tabular}

Table 3 shows that $88 \%$ of infants have a LBW,three quarters of them are preterm and $58 \%$ of both LBW and preterm babies included in the study were born via caesarean section. 


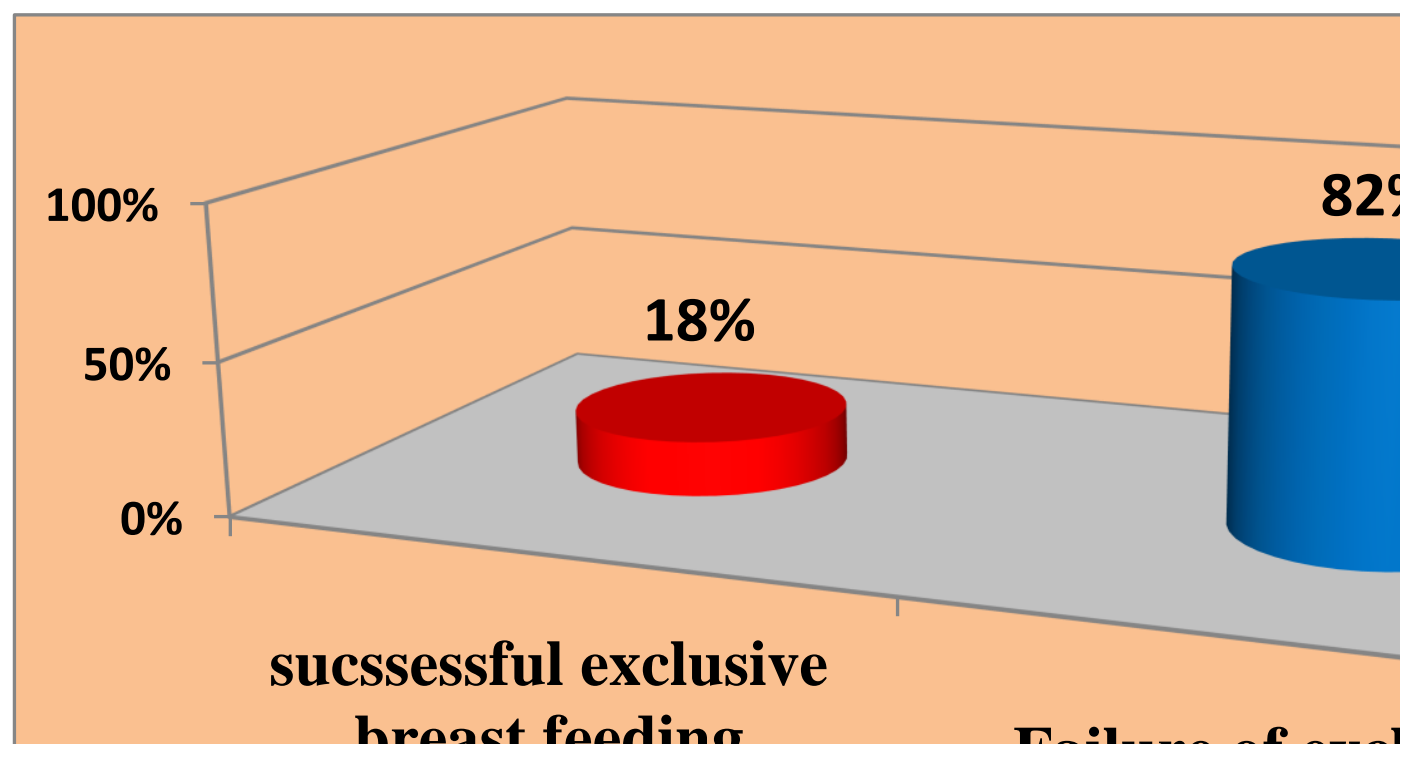

Figure 1: Distribution of Mothers by Exclusive Breast Feeding in the First Six Months of Life (N=200).

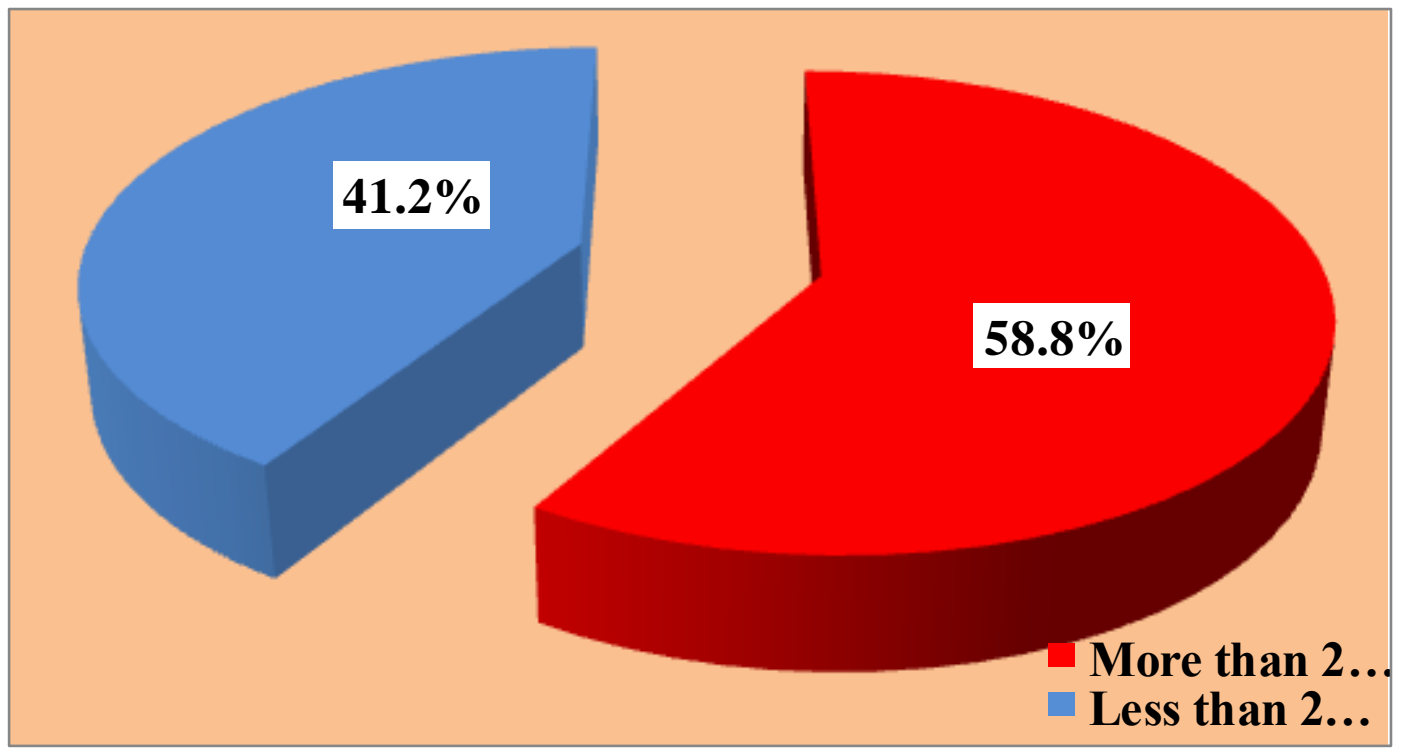

Figure 2:Distribution of Mothers (Gravida Two and More by Spacing Between Births in Years (n=136) 
Table 4:Distribution of Mothers by Obstetrical Characteristics of Mothers (N=200).

\begin{tabular}{|c|c|c|}
\hline Variables & Number & Percentage $(\%)$ \\
\hline \multicolumn{3}{|l|}{ Gravida } \\
\hline Primi & 64 & $32 \%$ \\
\hline Multi & 136 & $68 \%$ \\
\hline Total & 200 & $100 \%$ \\
\hline \multicolumn{3}{|l|}{ Previous CS } \\
\hline Yes & 68 & $34 \%$ \\
\hline No & 132 & $66 \%$ \\
\hline Total & 200 & $100 \%$ \\
\hline $\begin{array}{l}\text { Spacing(years) } \\
(\mathrm{n}=136)\end{array}$ & & \\
\hline More than 2 years & 80 & $58.8 \%$ \\
\hline Less than 2 years & 56 & $41.2 \%$ \\
\hline Total & 136 & $100 \%$ \\
\hline \multicolumn{3}{|l|}{ Procedure related to breast } \\
\hline Yes & 4 & $2 \%$ \\
\hline No & 196 & $98 \%$ \\
\hline Total & 200 & $100 \%$ \\
\hline
\end{tabular}

Table 4 shows that more than one third of mothers $(41.2 \%)$ have birth spacing less than two years (close spacing), and one third have already undergone a previous cesarean section.

Table 5: Reasons Cited by Respondents for Non- Exclusive Breast Feeding ( $N=164)$.

\begin{tabular}{|l|c|c|}
\hline \multicolumn{1}{|c|}{$\begin{array}{c}\text { Causes cited of not exclusively breast } \\
\text { feeding }\end{array}$} & Number & Percentage (\%) \\
\hline $\begin{array}{l}\text { Poor quality of milk, cause jaundice or } \\
\text { diarnea, previous child didn't thrive on } \\
\text { BF }\end{array}$ & 88 & $53.7 \%$ \\
\hline $\begin{array}{l}\text { Advice from doctor/medical staff, or } \\
\text { non-medically qualified person }\end{array}$ & 36 & $22.0 \%$ \\
\hline LBW and prematurity per se & 24 & $14.6 \%$ \\
\hline Her child refuse BF & 8 & $4.9 \%$ \\
\hline $\begin{array}{l}\text { Medical problems in the mother and } \\
\text { nipple problems }\end{array}$ & 4 & $2.4 \%$ \\
\hline Working mother, or being a student. & 164 & $2.4 \%$ \\
\hline Total & 4 & $100 \%$ \\
\hline
\end{tabular}


Table 5 shows that the three main groups of reasons in order of frequency for quitting exclusive breast feeding, the first group being (poor quality of milk, breast milk causes jaundice or diarrhea, and a previous child didn't thrive on breast feeding), the second group being (advice from doctor/medical staff, or non-medically qualified person) and (LBW and prematurity).

Table 6: Mean Difference of Birth Weight and Gestational Age According to Type of Feeding in the First Six Months of Life $(\mathrm{N}=\mathbf{2 0 0})$.

\begin{tabular}{|l|l|c|c|c|c|}
\hline \multicolumn{1}{|c|}{ Variable } & \multicolumn{1}{|c|}{ Type of feeding } & N & Mean \pm SD & t-test & P-value \\
\hline Birth \\
weight(gm) & Exclusive breast feeding & 36 & $2127.78 \pm 304.36$ & 3.426 & $\mathbf{0 . 0 0 0 1 *}$ \\
& Mixed \& artificial feeding & 164 & $1842.68 \pm 477.92$ & & 2.416 \\
\hline Gestational \\
age(weeks) & Exclusive breast feeding & 36 & $35.44 \pm 1.44$ & & $\mathbf{0 . 0 1 7} *$ \\
& Mixed\& artificial feeding & 164 & $34.20 \pm 3.02$ & & \\
\hline
\end{tabular}

$P$ value $\leq 0.05$ was significant

An independent $t$ test was conducted in table 6 to determine if a difference existed between the mean birth weight and gestational age with the type of infant feeding in the first six months of life, in both cases they are statistically significant ( $\mathrm{p}$ values are 0.0001 and 0.017 respectively).

Table 7: Association Between Maternal Socio-demographic Factors and Type of Feeding of Their Infant in the First Six Months of Life (N=200).

\begin{tabular}{|c|c|c|c|c|c|}
\hline \multirow[t]{2}{*}{ Variables } & \multicolumn{2}{|c|}{ Types of feeding } & \multirow[t]{2}{*}{ Total } & \multirow[t]{2}{*}{$\mathrm{X}^{2}$} & \multirow[t]{2}{*}{$\overline{P \text { value }}$} \\
\hline & $\begin{array}{l}\text { Exclusive breast } \\
\text { feeding }\end{array}$ & $\begin{array}{l}\text { Mixed and } \\
\text { artificial } \\
\text { feeding }\end{array}$ & & & \\
\hline $\begin{array}{l}\text { Residence } \\
\text { Urban } \\
\text { Rural } \\
\text { Total }\end{array}$ & $\begin{array}{ll}20(55.6 \%) & 96(5 \\
16(44.4 \%) & 68( \\
36(100 \%) & 164\end{array}$ & $\begin{array}{l}8.5 \%) \\
1.5 \%) \\
100 \%)\end{array}$ & $\begin{array}{l}116(58.0 \%) \\
84(42.0 \%) \\
200(100 \%)\end{array}$ & 0.108 & 0.743 \\
\hline $\begin{array}{l}\text { Educational level } \\
\text { Illiterate } \\
\text { Primary } \\
\text { Secondary } \\
\text { Higher education } \\
\text { Total }\end{array}$ & $\begin{array}{lr}12(33.3 \%) & 32( \\
20(55.6 \%) & 100 \\
0(0.0 \%) & 24( \\
4(11.1 \%) & 8(4 \\
36(100 \%) & 164\end{array}$ & $\begin{array}{l}9.5 \%) \\
(61.0 \%) \\
4.6 \%) \\
9 \%) \\
(100 \%)\end{array}$ & $\begin{array}{l}44(22.0 \%) \\
120(60.0 \%) \\
24(12.0 \%) \\
12(6.0 \%) \\
200(100 \%)\end{array}$ & & $0.008 * \mathrm{f}$ \\
\hline $\begin{array}{l}\text { Employment } \\
\text { Employed } \\
\text { House wife } \\
\text { Total }\end{array}$ & $\begin{array}{l}4(11.1 \%) \\
32(88.9 \%) \\
36(100 \%)\end{array}$ & $\begin{array}{l}3 \%) \\
92.7 \%) \\
100 \%)\end{array}$ & $\begin{array}{l}16(8.0 \%) \\
184(92.0 \%) \\
200(100 \%)\end{array}$ & & $0.496^{\mathrm{f}}$ \\
\hline
\end{tabular}


$* \mathrm{P}$ value $\leq 0.05$ was significant.

f:fisher-exact test.

Chi square test was conducted in table 7 to show the association between maternal socio-demographic factors and type of feeding of their infants in the first six months of life ,there is a significant association of maternal level of education and type of infant feeding in the first six months of life weather exclusive breast feeding or mixed and artificial feeding $(\mathrm{p}=0.008)$.

Table 8: Association between maternal obstetrical characteristics and type of feeding of their infant in the first six months of life $(\mathrm{N}=\mathbf{2 0 0})$.

\begin{tabular}{|c|c|c|c|c|c|}
\hline \multirow[t]{2}{*}{ Variables } & \multicolumn{2}{|c|}{ Types of feeding } & \multirow[t]{2}{*}{ Total } & \multirow[t]{2}{*}{$\overline{X^{2}}$} & \multirow[t]{2}{*}{ P value } \\
\hline & $\begin{array}{l}\text { Exclusive } \\
\text { breast feeding }\end{array}$ & $\begin{array}{l}\text { Mixed and } \\
\text { artificial } \\
\text { Feeding }\end{array}$ & & & \\
\hline \multicolumn{6}{|l|}{ Gravida } \\
\hline Primi & \multicolumn{2}{|c|}{$23(63.9 \%) \quad 6(3.7 \%)$} & $29(14.5 \%)$ & \multirow[t]{3}{*}{86.38} & \multirow[t]{3}{*}{$0.0001 *$} \\
\hline Multi & \multicolumn{2}{|c|}{$13(36.1 \%) \quad 158(96.3 \%)$} & $171(85.5 \%)$ & & \\
\hline Total & $36(100 \%)$ & $164(100 \%)$ & $200(100 \%)$ & & \\
\hline \multicolumn{6}{|l|}{ Type of delivery } \\
\hline Normal vaginal delivery & \multicolumn{2}{|c|}{$16(44.4 \%) \quad 68(41.5 \%)$} & $84(42.0 \%)$ & \multirow[t]{4}{*}{3.447} & \multirow[t]{4}{*}{0.178} \\
\hline Emergency C-section & \multirow{3}{*}{\multicolumn{2}{|c|}{$\begin{array}{ll}8(22.2 \%) & 60(36.6 \%) \\
12(33.3 \%) & 36(22 \%) \\
36(100 \%) & 164(100 \%)\end{array}$}} & \multirow{3}{*}{$\begin{array}{l}68(34.0 \%) \\
48(24.0 \%) \\
200(100 \%)\end{array}$} & & \\
\hline Elective C-section & & & & & \\
\hline Total & & & & & \\
\hline \multicolumn{6}{|l|}{$\begin{array}{c}\text { Spacing(years) } \\
(\mathbf{n}=136)\end{array}$} \\
\hline$\geq 2$ years & \multicolumn{2}{|c|}{$12(33.3 \%) \quad 68(68 \%)$} & $80(58.8 \%)$ & \multirow[t]{3}{*}{13.134} & \multirow[t]{3}{*}{$0.0001 *$} \\
\hline$<2$ years & \multirow{2}{*}{\multicolumn{2}{|c|}{$\begin{array}{lc}24(06.1 \%) & 32(32 \%) \\
36(100 \%) & 100(100 \%)\end{array}$}} & $65(41.2 \%)$ & & \\
\hline Total & & & $136(100 \%)$ & & \\
\hline
\end{tabular}

$* \mathrm{P}$ value $\leq 0.05$ was significant.

Chi square test was conducted in table 8 to show the association between maternal obstetrical characteristics and type of feeding of their infants in the first six months of life.

There is a significant association between (gravida, spacing between births) and the type of infant feeding whether exclusive breast feeding or mixed and artificial feeding $(\mathrm{p}<0.05)$. 


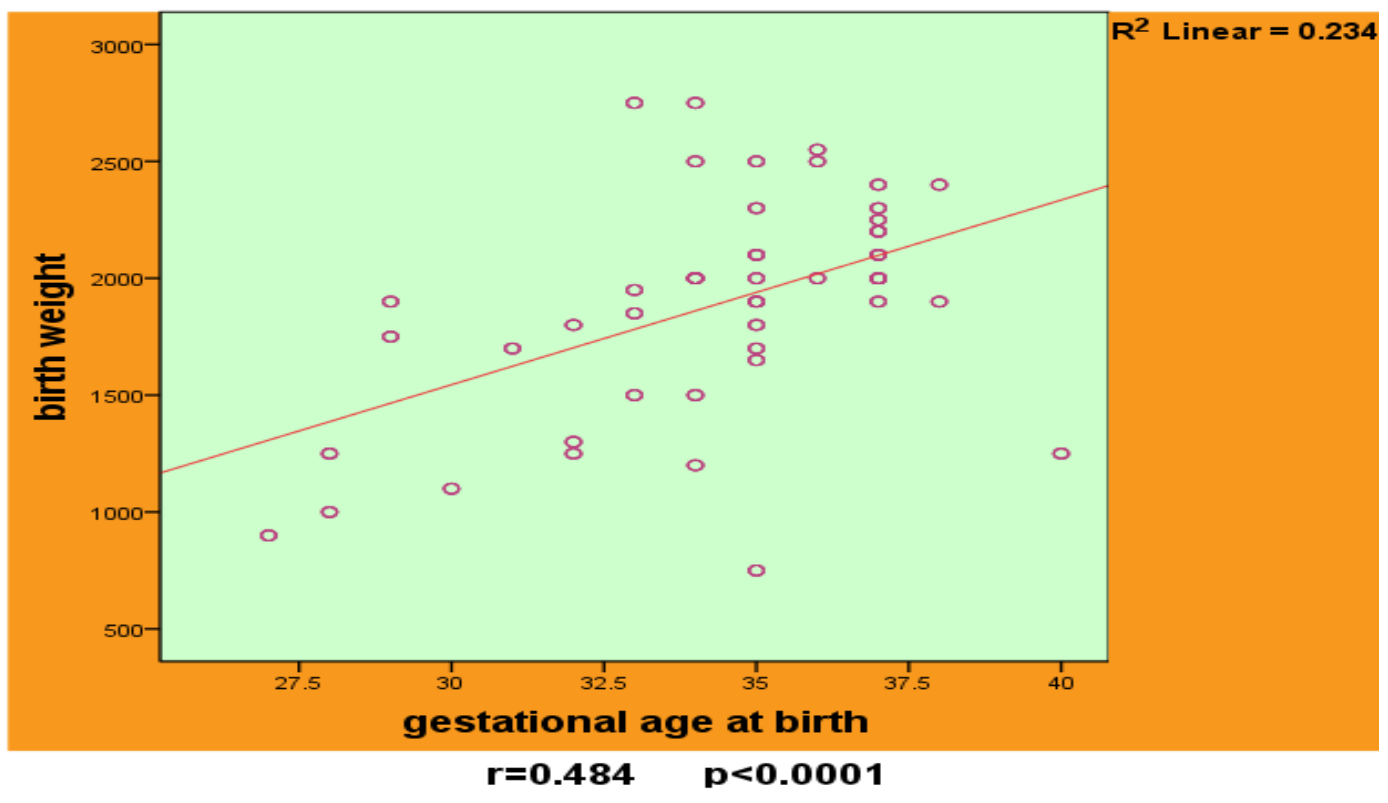

Figure 3: Correlation of Gestational Age at Birth and Birth Weight of the Infants.

Figure 3 shows a direct moderate significant correlation between gestational age and birth weight of infants included in the $\operatorname{study}(\mathrm{r}=0.484, \mathrm{p}$ value $<0.0001$ which is significant $)$

\section{7- Discussion:}

Human milk is the ideal source of nutrition for all neonates, but there is controversy and confusion regarding its use as a nutrition source for preterm and low birth weight infants in Babylon Province in central Iraq. However current scientific data supports the use of human milk for low birth weight and preterm infants (6). This study was undertaken to evaluate the rates of exclusive breast feeding of both preterm and term small for gestational age, low birth weight infants nursed on exclusive breast milk from birth to six months of age. The mean age at marriage of respondents in this study is $(19.45 \pm 5.10)$ years.

Since all the babies included in the study were either preterm or low birth weight, the mean birth weight is $(1894.00 \pm 464.15) \mathrm{gm}(\mathrm{LBW})$ and the mean gestational age is $(34.42 \pm 2.84)$ weeks (preterm). When low birth weight infants, both the preterm and the term small for gestational age, were exclusively breastfed by their own mothers, they gained weight and had an increase in their head circumference and length to the levels almost comparable to the standard fetal- infant growth norms. Low birth weight is a common problem in Babylon Province with an incidence of $15-30 \%$. Breastfeeding is the safest and most natural form of infant feeding, and it should be exclusive up to the sixth month (7). Complementary feeding should be implemented, after the sixth month but breastfeeding can be maintained up to the second year of life or longer (8). Human milk provides a unique combination of proteins, lipids, carbohydrates, minerals, vitamins, enzymes and living cells, in addition to offering nutritional, immunological, psychological and economic benefits (9). These qualities have great importance when it comes to preterm newborns, due to their vulnerability (10).

The medical literature also provides evidence that mothers of preterm and low birth weight infants should have access to breastfeeding support, in order to maintain a sufficient milk production; however, practical aspects regarding the promotion of human milk feeding still have not been settled into the routine care of preterm infants in most neonatal units(11). In Hilla the provincial capital of Babylon province there is one functioning central neonatal intensive care unit (NICU)and another special care baby unit (SCBU), with a brand new (NICU) to be opened officially. Hospitals are supposed to encourage breast feeding, but major pitfalls are evident and it is common to see artificial milk formulas inside these units.

Our data also suggests that the reasons why mothers stop breastfeeding vary with the age of their infant when they were weaned. The most frequently reported reasons for discontinuing breastfeeding within the first month were related to locational and nutritional factors. This finding supports a recommendation by Taveras et al(12) that breastfeeding interventions should focus on lactational and nutritional counseling for mothers during their postpartum hospitalization and shortly after they are discharged. The Baby Friendly Hospital Initiative, a program designed to help mothers get a good start in nursing, has been shown to be effective in helping mothers initiate and maintain breastfeeding (13). 
The recommendation of breastfeeding for preterm and low birth weight infants has been advocated based on the immunological properties of human milk, on its role in gastrointestinal maturation, on the establishment of mother and infant bonding and on the improved neurobehavioral performance of breastfed infants (14). During breastfeeding, suckswallow coordination of preterm infants is enhanced. It has been confirmed that the levels of transcutaneous oxygen partial pressure, oxygen saturation, and body temperature are higher than those obtained during bottle-feeding(15), thus corroborating that breastfeeding has far more physiological advantages. The incidence of any infection, including necrotizing enterocolitis, sepsis and meningitis, is significantly lower in very low birthweight (VLBW) infants fed human milk, when compared to those fed only artificial milk (16).

These scientific facts are hard to deliver to young mothers in Babylon province.

The study shows that mothers who participated in the study are married at a relatively young age,52\% are aged between age 10 to 19 years reflecting the nationwide problem of underage marriage which has emerged as a result of years of strife and economic hardship in Iraq. Four fifths $(82 \%)$ of these women are either illiterate or have primary level of education, nine out of ten (92\%) are housewives.

The significant benefits of breastfeeding for children, mothers, and society are widely recognized. A series of studies conducted in industrialized countries has shown that preterm and low birth weight infants who are not breastfed for at least 6 months are 3.5 times more likely than those who are to be hospitalized for respiratory infections such as pneumonia or asthma, (17) 2 times more likely to suffer from diarrhea,1.6 times more likely to suffer from ear infection(18), 1.5 times more likely to become overweight during childhood(19). Because of the numerous benefits of breastfeeding, the American Academy of Pediatrics Section on Breastfeeding recommends that mothers breastfeed exclusively for approximately the first 6 months after their child's birth and continue breastfeeding for at least the first year of their child's life. Scientific literature on natural breastfeeding of preterm and low birth weight infants, does not clearly define breastfeeding at hospital discharge and does not specifically describe the available breastfeeding promotion programs (20).

In local neonatal units in Babylon some breastfeeding promotion policy is employed, although it is far from stringent and is lax. Likewise, this is the reality in most neonatal intensive care units around the world, since hospitalized preterm and low birth weight infants still are deprived of the presence of their mother and of breastfeeding $(21)$.

Our study shows that (88\%) of infants have a low birth weight(LBW), three quarters of them are preterm and 58\% of both LBW and preterm babies included in the study were born via caesarean section.

In Europe, similar studies have been carried out. A comparative study of 100 preterm infants and 108 full-term infants born in a maternity ward where the mother was encouraged to continue breastfeeding and to establish a bonding with her preterm infant revealed that $96.3 \%$ of full-term babies and $96 \%$ of preterm and low birth weight infants were discharged from hospital receiving breastmilk, but those women who gave birth to full-term babies showed a higher rate of exclusive breastfeeding: $88.9 \%$ versus 55\%(22).In a Swedish neonatal unit(23), where natural breastfeeding was the rule, $93 \%$ of 70 LBW infants were discharged from hospital receiving breast milk. In this group, $10 \%$ had a birth weight lower than $1,500 \mathrm{~g}$.

As with underage marriage the problem of close spacing between births and poor family planning compliance is a national health problem in Iraq. Our study shows that more than one third of mothers $(41.2 \%)$ have birth spacing less than two years (close spacing), and one third have already undergone a previous cesarean section.

Breastfeeding, even with its advantages and many features designed to make it easier, is an undervalued practice in Iraq. Early weaning may lead to the interruption of proper oral motor development (24), this weaning is influenced by demographic variables (type of birth, maternal age, spacing between births, the child's father share), socioeconomic (family income, maternal and paternal education), attached to the assistance prenatal care (guidance about the importance gift breastfeeding) and the immediate post-natal care (aid health professionals) (25).

The study cited three main groups of reasons in order of frequency for quitting exclusive breast feeding in preterm and low birth weight infants less than six months of age. A major cause was the notion that breast milk is of a poor quality and that it is inferior to formula milk. They believe that is a cause of jaundice or diarrhea. They also site a negative experience with natural feeding stating that a previous child didn't thrive on breast feeding. The second major group for quitting breastfeeding was because of advice from doctor or medical staff, or non-medically qualified person against continuation of breastfeeding. Last but not least because of low birth weight per se and or prematurity.

In an international study (26), the perception that their infant was not satisfied by breast milk alone was cited consistently as one of the top three reasons in the mothers' decision to stop breastfeeding regardless of weaning age (43.5\%-55.6\%). Mothers' concerns about lactation and nutrition issues were the most frequently cited reasons for stopping breastfeeding during the first 2 months. Starting from the third month, self-weaning reasons were increasingly cited as important, with the statements "My baby began to bite" (31.7\%), "My baby lost interest in nursing or began to 
wean himself or herself" (47.3\%), and "Breast milk alone did not satisfy my baby" (43.5\%) cited as the top 3 reasons(27) .

The study is also mirrored in an international study. A study conducted with 427 children between 3 and 6 years of age, showed that the mother who obtained knowledge about the importance of breastfeeding and breastfed their children exclusively for six months or close to this period (28).

Among mothers who stopped breastfeeding through the first 6 months of their infant's life, the perception of their child's dissatisfaction with breast milk alone and concerns about milk supply were both consistently cited as important reasons for stopping, and their child's dissatisfaction with breast milk was continuously cited as a top reason even among women who stopped breastfeeding after 6 months(29). When a mother does not have confidence that she is providing an adequate quantity or quality of milk for her infant, she is likely to stop breastfeeding regardless of her infant's age. Results of previous studies have similarly suggested that insufficient milk supply was a leading reason that mothers reported for their decision to stop breastfeeding(30). Studies from industrialized nations showed that $>50 \%$ of breastfeeding women perceived their milk supply to be low during the early months of breastfeeding, although their infants seemed satisfied and were not underweight (31). Because of difficulty in estimating the percentage of mothers whose milk supply is truly insufficient, data on the prevalence of insufficient milk supply among breastfeeding mothers are limited. However, in four studies of self-selected populations of women who decided to breastfeed exclusively for at least 3 to 4 months, $<5 \%$ of the mothers were unable to produce enough milk to accomplish their infant's weight gain(32).

These results suggest that women's perception of having a low milk supply might, in many cases, be attributable to their lack of knowledge regarding the normal process of lactation or to technical difficulties in feeding rather than to an actual inability to produce a sufficient quantity of milk. They also suggest that most mothers can overcome temporary breastfeeding problems without resorting to supplementation if they receive appropriate guidance from health professionals, including reassurance that what they perceive to be a low milk supply is actually sufficient and that infant growth is uneven and often occurs in spurts(33).

An independent $t$ test was conducted in the study to determine if a difference existed between the mean birth weight and gestational age with the type of infant feeding in the first six months of life, in both cases they are statistically significant ( $\mathrm{p}$ values are 0.0001 and 0.017 respectively).

In Brazil, Xavier et al.(34) obtained a breastfeeding rate of $86.5 \%$ at hospital discharge, when studying a population of 222 LBW infants, of whom 50.5\% were preterm, in a nursery of a teaching hospital of Ribeirão Preto, where the mother's own milk was the food of choice for the newborn. The hospital had a human milk bank and provided meetings for the mothers for breastfeeding promotion. In Campinas, the assessment of newborns with a long hospital stay at a neonatal unit where preterm births amounted to $43.9 \%$, demonstrated $88.9 \%$ of breastfeeding at hospital discharge. The hospital employed breastfeeding promotion, characterized by recommending early milk expression, stimulating the mother to care for her hospitalized infant, and facilitating her readmission for breastfeeding (35).

In another international study, the frequency of breastfeeding among 131 mothers of infants with birth weight less than or equal to $2,500 \mathrm{~g}$ was of $91 \%$ at a neonatal unit that offered lactation consultancy for teaching breastfeeding practices to mothers and hospital staff. Next to this unit, there was a comfortable, especially designed place where mothers were encouraged to express breast milk and breastfeed as soon as the infant's clinical conditions allowed so(36). In Switzerland, a study involving 327 infants admitted to a neonatal intensive care unit, which often treats a small number of VLBW infants $(10.8 \%)$, showed a breastfeeding rate of $75 \%$. Since there was no hospital accommodation for the mothers, they were encouraged to visit their children every day to bring them the expressed milk and receive instructions about breastfeeding. Breast feeding was initiated as soon as the infant's clinical conditions stabilized (37).

Chi square test was conducted in table 7 to show the association between maternal socio-demographic factors and type of feeding of their infants in the first six months of life ,there is a significant association of maternal level of education and type of infant feeding in the first six months of life whether exclusive breast feeding or mixed and artificial feeding $(\mathrm{p}=0.008)$.

In the present study $40 \%$ (G1) of the interviewed mothers have not completed elementary school; and G2, 43\% of them on grade level in elementary education. The level of education is one of the factors that can interfere with difficulty breastfeeding. The literature states that this variable maternal education is correlated with early weaning, so the longer duration of the mother's education time about breastfeeding, demonstrating that cultural aspects that start in the context of maternal and child relationship extend to family and the community(38).

Another study found that $75,9 \%$ of mothers stopped breastfeeding without medical advice. $38,9 \%$ reported that milk was "weak" or "dried" or that the child "dropped" the chest. They also observed that education was related to longer breastfeeding periods ( $\mathrm{p}=0,016$ and $\mathrm{p}=0,011$ respectively)(39). 
In developed countries, mothers with higher levels of education tend to breastfeed longer. However,a study (40) in Porto Alegre found that while inhabiting a developing country, mothers followed the model of developed countries, ie, those with higher educational level breastfed longer.

Chi square test was conducted (see table 8 ) to show the association between maternal obstetrical characteristics and type of feeding of their infants in the first six months of life.

There is a significant association gravida, spacing between births and type of infant feeding in the first six months of life whether exclusive breast feeding, mixed or artificial feeding $(\mathrm{p}<0.05)$.

In the USA, there are few studies with representative samples of the preterm and low birth weight population admitted to neonatal units. Most of them select the sample based on the mother's decision to breastfeed. This is a result of the low breastfeeding rates observed in U.S. hospitals: 52.2\% in 1990 and 59.7\% in 1995,128 far from the aim of the U.S. Health Department, which intends to reach $75 \%$ of breastfeeding in the immediate puerperium(41).

\section{8- Conclusion}

Our findings about the major reasons why mothers of preterm and low birth weight infants stop breastfeeding at various times during their child's first six months of life should be useful to health professionals when attempting to help mothers overcome breastfeeding barriers. The study also helps health officials in their attempt to devise targeted breastfeeding interventions on those issues prominent for each infant age.

Our study concludes that:

1-The major cause of quitting breast feeding in such infants was the negative attitude of nursing mother in terms of the poor nutritional quality and quantity of breast milk.

2-Another major cause concluded from our study is that breast milk causes neonatal jaundice and/or diarrhea as perceived by the nursing mothers.

3-Our study also conclude that mothers tend to quit breast feeding because a previous child didn't thrive and had stunted growth as alleged.

\section{9- Recommendations:}

1-To improve the feeding and nutrition of preterm and low birth weight infants, the care provided by hospitals in Babylon should go through some changes. It is essential that medicine practiced at neonatal units not be based only on high technology, but also consider the humanization of care. Even after discharge from hospital follow up of these neonates should be provided by qualified professionals, providing individualized care, and allowing more interaction between parents and infants.

2-Parents of preterm and LBW infants should be regarded as collaborators and should not be excluded in the effort to promote exclusive breast feeding infant and their cooperation and attitude's should be indispensable for healthy psychomotor development and bonding that is gained from exclusive breastfeeding.

3-Myths and deeply held misconceptions about the quality and quantity of breast milk should be busted and engaged through improved education and better coverage in the mass and social media.

\section{0- Acknowledgment:}

This study was accomplished with the assistance of a group of medical students who kindly collected some of the data from the respondents.

\section{CONFLICT OF INTERESTS}

There are no conflicts of interest.

\section{References:}

[1] Lawrence PB.’Breast milk: Best source of Nutrition for Term and Preterm Infants". Pediatr Clin North Am. 41:925-941. 1994.

[2]Meharban S. Disorders of weight and gestation. In: Meharban S, editor. Care of the newborn. 6th ed. Sagar publications; New Delhi: p. 219. 2004.

[3] Li R, Fridinger F, Grummer-Strawn L. "Public perceptions on breastfeeding constraints". J Hum Lact. 18 (3):227235. 2002.

[4] Kumar P, Nangia S, Saili A, Dutta AK." Growth and morbidity patterns of exclusively breast-fed preterm babies". Indian Pediatr. 36:296-300. [PubMed]. 1999. 
[5] Fenton TR. "A new growth chart for preterm babies: Babson and Benda's chart updated with recent data and a new format". BMC Pediatr. 3:13. [PubMed]. 2003.

[6] Schanler RJ, Atkinson SA. "Effects of nutrients in human milk on the recipient premature infant". J Mammary Gland Biol Neoplasia. 4:297-307. 1999.

[7] Jarvenappa AL, Raiha NC, Rassin DK, Gaull GE. Preterm infants fed human milk attain intrauterine weight gain. Acta Pediatr Scand. 72:239-243. 1983.

[8] Gross SJ. "Growth and biochemical responses of preterm infants fed human milk or modified infant formula". $N$ Eng J Med. 1983;308:237-241.

[9] Cooper PA, Rothberg AD, Pettifor JM, Bolton KD, Devenhuis S. "Growth and biochemical response of premature infants fed pooled preterm milk or special formula". J Pediatr Gastroenterol Nutr. 3:749-754. 1984.

[10] Cooper PA, Rothberg AD, Davies VA, Argent AC."Comparative growth and biochemical response of very low birth weight infants fed on own mothers' milk, a premature infant formula, or one of the two standard formulas". $J$ Pediatr Gastroenterol Nutr. 4:786-794. 1985.

[11] Hendrickse WA, Spencer SA, Roberton DM, Hull D. "The caloric intake and weight gain of LBW infants fed on fresh breast milk or special formula milk". Eur J Pediatr. 143:49-53. 1984.

[12] Taveras EM, Capra AM, Braveman PA, Jensvold NG, Escobar GJ, Lieu TA." Clinician support and psychosocial risk factors associated with breastfeeding discontinuation". Pediatrics.;112 (1 pt 1):108-115 2003.

[13] Singhal A, Cole TJ, Lucas A. Early nutrition in preterm infants and later blood pressure - two cohorts after randomized trials. Lancet. 357:413-419. 2001.

[14] Ravelli AC, Meulen JH, Osmond C, Barker DJ, Bleker OP.'Infant feeding and adult glucose tolerance, lipid profiles, blood pressure, and obesity". Arch Dis Child. 82:248-252. 2000.

[15] Von Kries R, Koletzko B, Sauerwald T, Von Mutius E, Barnert D, Grunert V." Breast feeding and obesity: cross sectional study". Brit Med J. 319:147-150. 1999.

[16] Tudehope DI, Mitchell F, Cowley DM. "A comparative study of a premature infant formula and preterm breast milk for low birth weight infants". Aust Pediatr J. 1986;22:199-205.

[17] Cushing AH, Samet JM, Lambert WE, et al. "Breastfeeding reduces risk of respiratory illness in infants". Am $J$ Epidemiol. 147 (9):863- 870. 1998.

[18] Howie PW, Forsyth JS, Ogston SA, Clark A, Florey CD. "Protective effect of breast feeding against infection". BMJ. 300 (6716):11- 16. 1990.

[19] Fewtrell MS, Morley R, Lucas A. "The effects of dietary intervention on the postnatal growth of term SGA infants". Am J Clin Nutr. 74:516-523. 2001.

[20] Awasthi S, Mishra PK, Malik GK. "Is high protein milk beneficial for SGA-terms?” Indian Pediatr. 26:45-51. 1989.

[21] Sur D, Mondal SK, Gupta DN. "Impact of breast feeding on weight gain and incidence of diarrhoea among low birth weight infants of urban slum of Calcutta". Indian Pediatr. 38:381-384. 2001.

[22] Meberg A, Willgraff S, Sande HA. "High potential for breast feeding among mothers giving birth to pre-term infants". Acta Paediatr Scand. 71:661-2. 1982.

[23]Flacking R, Nyqvist KH, Ewald U, Wllin L. "Long-term duration of breastfeeding in Swedish low birth weight infants". J Hum Lact. 19:157-65. 2003.

[24]Nafstad P, Jaakkola JJ, Hagen JA, Botten G, Kongrud J. "Breastfeeding, maternal smoking, and lower respiratory tract infections". Eur Respir J.;9 (12):2623-2629. 1996.

[25]Oddy WH, Holt PG, Sly PD, et al. "Association between breast feeding and asthma in 6-year-old children: findings of a prospective birth cohort study". BMJ. 319 (7213):815-819. 1999.

[26]Oddy WH, Sly PD, de Klerk NH, et al. "Breast feeding and respiratory morbidity in infancy: a birth cohort study". Arch Dis Child. 88 (3):224- 228. 2003.

[27] Ahluwalia IB, Morrow B, Hsia J. "Why do women stop breastfeeding? Findings from the Pregnancy Risk Assessment and Monitoring System". Pediatrics. 116 (6):1408-1412. 2005.

[28]Scariati P, Grummer-Strawn L, Beck Fein S. "A longitudinal analysis of infant morbidity and the extent of breastfeeding in the United States". Pediatrics. 99 (6). 1997. 
[29]Raisler J, Alexander C, O'Campo P."Breast-feeding and infant illness: a dose-response relationship?". Am J Public Health.;89 (1):25- 30. 1999.

[30]Owen MJ, Baldwin CD, Swank PR, Pannu AK, Johnson DL, Howie VM. "Relation of infant feeding practices, cigarette smoke exposure, and group child care to the onset and duration of otitis media with effusion in the first two years of life". J Pediatr. 123 (5):702-711. 1993.

[31]Duffy LC, Faden H, Wasielewski R, Wolf J, Krystofik D.”Exclusive breastfeeding protects against bacterial colonization and day care exposure to otitis media”. Pediatrics100 (4). 1997.

[32]Duncan B, Ey J, Holberg CJ, Wright AL, Martinez FD, Taussig LM. "Exclusive breast-feeding for at least 4 months protects against otitis media”. Pediatrics. 91 (5):867-872. 1993.

[33]Gillman MW, Rifas-Shiman SL, Camargo CA, et al. "Risk of overweight among adolescents who were breastfed as infants". JAMA.285 (19):2461-2467. 2001.

[34]Xavier CC, Jorge MS, "Gonçalves AL. Prevalência do aleitamento materno em recém-nascidos de baixo peso". Rev Saúde Públ. 25:381-7. 1991.

35.Toschke AM, Vignerova J, Lhotska L, Osancova K, Koletzko B, von Kries R. "Overweight and obesity in 6- to 14year old Czech children in 1991: protective effect of breast-feeding”. J Pediatr. 141 (6):764-769. 2002.

[36]Von Kries R, Koletzko B, Sauerwald T, von Mutius E. "Does breast-feeding protect against childhood obesity?." Adv Exp Med Biol. 478 :29- 39. 2000.

[37]Strbák V, Skultétyová M, Hromadová M, Randusková A, Macho L. "Late effects of breast-feeding and early weaning: seven-year prospective study in children". Endocr Regul.;25 (1-2):53-57. 1991.

[38]American Academy of Pediatrics, "Section on Breastfeeding. Breastfeeding and the use of human milk". Pediatrics. 2005;115 (2):496- 506

[39]Centers for Disease Control and Prevention. Breastfeeding rates by socio-demographic factors, among children born in 2004.

[40] Giugliane ERJ. "O aleitamento materno na prática clínica". j Pediatr. Rio de Janeiro, v.76. supl. 3, 2000.

[41] Henderson G, Anthony MY, McGuire W. "Formula milk versus maternal breast milk for feeding preterm or low birth weight infants". Cochrane Database Syst Rev. 4:2972. 2007.

اجزيت دراسة وصفيه مقطعية في مدينة الحلة مركز محافظة بابل وشملت . . رضيع لدراسة معدل انتشار الرضاعة الطبيعية المطلقة لدى الاطفال الخدج المبترين وناقصي الوزن .تراوحت اعمار الاطفال الرضع ما بين اليوم الاول من الولادة الى عمر الستة اثهر.

اجريت الدر اسة في وحدتي الخدج و العناية بالأطفال حديثي الو لادة في مسنتفى الحله التعليمي العام ومستشفى بابل التعليمي للنسائيه والاطفال مابين

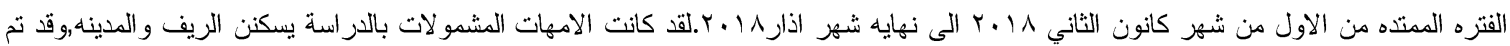

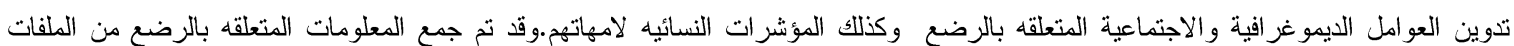

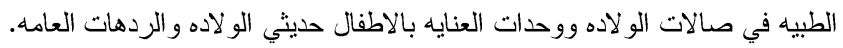

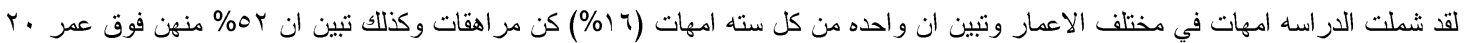

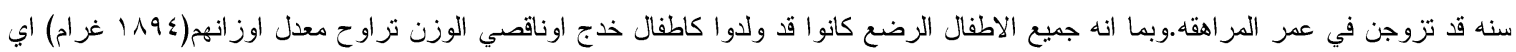

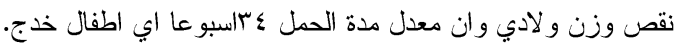

لقد اوضحت الدراسه ان هنالك ثلاثه مجاميع رئيسيه حسب الاهميه للعزوف عن الرضاعه الطبيعيه المطلقه في هذه الفئه من الاطفال الرضع

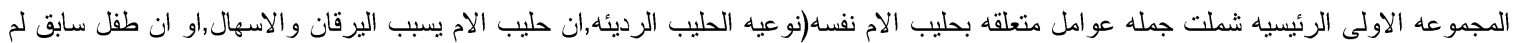

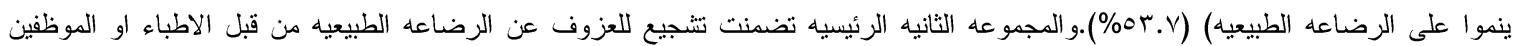

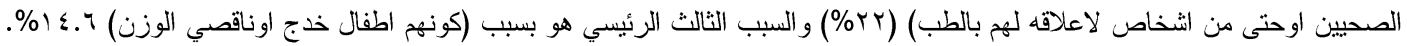
الكلمات الالة: الرضاعة الطبيعية الاطفال الخدج، نقص الوزن الو لادي. 